\title{
Critical Analysis for Life Cycle Assessment of Bio-Cementitious Materials Production and Sustainable Solutions
}

\author{
Adel Ali Al-Gheethi ${ }^{1, *(\mathbb{D})}$, Zubair Ahmed Memon ${ }^{2}{ }^{\mathbb{D}}$, Ali Tighnavard Balasbaneh ${ }^{3}$, Walid A. Al-Kutti ${ }^{4}$, \\ Norfaniza Mokhtar ${ }^{3}$, Norzila Othman ${ }^{3}$, Mohd Irwan Juki ${ }^{3, *}$, Efaq Ali Noman ${ }^{5}$ and Hassan Amer Algaifi ${ }^{3}$
}

check for updates

Citation: Al-Gheethi, A.A.; Memon, Z.A.; Balasbaneh, A.T.; Al-Kutti, W.A.; Mokhtar, N.; Othman, N.; Juki, M.I.; Noman, E.A.; Algaifi, H.A. Critical Analysis for Life Cycle Assessment of Bio-Cementitious Materials Production and Sustainable Solutions. Sustainability 2022, 14, 1920. https://doi.org/10.3390/su14031920

Academic Editor: Alessia Amato

Received: 25 December 2021

Accepted: 24 January 2022

Published: 8 February 2022

Publisher's Note: MDPI stays neutral with regard to jurisdictional claims in published maps and institutional affiliations.

Copyright: (C) 2022 by the authors. Licensee MDPI, Basel, Switzerland. This article is an open access article distributed under the terms and conditions of the Creative Commons Attribution (CC BY) license (https:// creativecommons.org/licenses/by/ $4.0 /)$.
1 Eco Hydrology Technology Research Centre (Eco-Hytech), Faculty of Civil Engineering \& Built Environment, Universiti Tun Hussein Onn Malaysia, Batu Pahat 86400, Johor, Malaysia

2 Department of Engineering Management, College of Engineering, Prince Sultan University, Riyadh 11586, Saudi Arabia; zamemon@psu.edu.sa

3 Department of Civil Engineering, Faculty of Civil Engineering and Built Environment, Universiti Tun Hussein Onn Malaysia, Batu Pahat 86400, Johor, Malaysia; tighnavard@uthm.edu.my (A.T.B.); norfaniza@uthm.edu.my (N.M.); norzila@uthm.edu.my (N.O.); hassanamer@uthm.edu.my (H.A.A.)

4 Department of Civil \& Construction Engineering, College of Engineering, Imam Abdulrahman Bin Faisal University, Dammam 34212, Saudi Arabia; wasalem@iau.edu.sa

5 Department of Applied Microbiology, Faculty of Applied Sciences, Taiz University, Taiz 6803, Yemen; eanm1984@gmail.com

* Correspondence: adel@uthm.edu.my or adelalghithi@gmail.com (A.A.A.-G.); irwan@uthm.edu.my (M.I.J.); Tel.: +60-07-456-4316 or +60-0-111-1098-362 (A.A.A.-G.); +60-19-775 8186 (M.I.J.);

Fax: +607-453-6588 (A.A.A.-G.)

\begin{abstract}
The purpose of this study is to study the life cycle assessment of biocementitious materials production in comparison to traditional cement materials production. The environmental impact of production processes over the life cycle was evaluated on the basis of global warming and ozone depletion, human health, land, freshwater, marine ecotoxicity, and natural water system eutrophication. LCA uses endpoint methods (ECO indicators) and SimaPro 8 software to assess the health and environmental impact of raw materials used in the production process, including cement, $\mathrm{Ca}\left(\mathrm{NO}_{3}\right)_{2} \cdot 4 \mathrm{H}_{2} \mathrm{O}$, urea, molasses, and electricity. The results showed that cement materials made $82.88 \%$ of the world's warming in all raw materials used in production processes, $87.24 \%$ of the world's health, $89.54 \%$ of the deforestation of freshwater, and $30.48 \%$ to marine eutrophication. $\mathrm{Ca}\left(\mathrm{NO}_{3}\right)_{2} \cdot 4 \mathrm{H}_{2} \mathrm{O}$ contributes by $58.88 \%$ to ozone depletion, 15.37 to human carcinogenic toxicity, $3.19 \%$ to freshwater eutrophication, and $11.76 \%$ to marine eutrophication. In contrast, urea contributes $38.15 \%$ to marine eutrophication and $5.25 \%$ to freshwater eutrophication. Molasses contribute by $13.77 \%$ to marine eutrophication. Cement contributes $74.27 \%$ to human health damage, $79.36 \%$ to ecosystem damage; $\mathrm{Ca}\left(\mathrm{NO}_{3}\right)_{2} \cdot 4 \mathrm{H}_{2} \mathrm{O}$ contributes $13.54 \%$ to human health damage and $9.99 \%$ to ecosystem damage; while urea contributes $6.5 \%$ to human health damage and $5.91 \%$ to ecosystem damage. Bio-cementitious wastewater should undergo a treatment process to remove urea and molasses residues, as well as nitrates, before final disposal into the environment.
\end{abstract}

Keywords: global warming; human health; ecotoxicity; eutrophication; urea; molasses

\section{Introduction}

Cement is one of the most important and widely used construction materials; however, it plays a role as a pollutant and unfriendly material. The massive use of cementbased concrete causes several environmental problems, including carbon dioxide emissions in the manufacturing stage and soil and water source contamination in the disposal stage. For example, the annual global production of cement-based concrete is estimated at 10 billion cubic meters, and the volume of cement production separately reached 4180 million tons in 2014, which generates approximately $7 \%$ of global carbon dioxide emissions [1-3]. 
Such results also generate a variety of wastes accumulation such as cement concrete grinding residues, crushed concrete produced, fine cement, concrete waste, and others, which many studies have focused on finding environmental solutions to dispose of or recycle. In Romania, cementitious wastes are disposed of by burying them with other waste, which often requires large burial grounds and poses a significant environmental risk to air, soil, and water resources [4]. Moreover, many studies and experiments have attempted to reduce the environmental hazards of cement by replacing it with other environmentally friendly materials such as rice husk ash [5,6], fly ash [7], and other materials that have similar properties to cement. However, these materials have only been used as a partial replacement of cement [8].

In the same context, the formation of inevitable microcracks as well as porosity inside concrete matrix are also another challenge for civil engineers. These is because the lifespan of cement-based structure is reduced owing to penetration of aggressive ions and concrete microstructure destroying. This fact has also encouraged the civil engineering community to develop smart bio-concrete, namely self-healing concrete, to fill these microcracks as well as concrete pores by microbial calcium carbonate in recent years. Indeed, the concept of self-healing concrete is inspired by the remarkable human wound healing. In particular, microbial calcium carbonate is precipitated and deposited on the bacterial cells due to the chemical reactions between developed carbonate ions from metabolic activity and calcium ions are generated inside the concrete matrix. This microbial calcium carbonate proved its ability to heal concrete cracks up to $0.4 \mathrm{~mm}$; however, the healing efficiency in the deeper part of cracks is still limited [9-13]. In addition, this phenomenon, called microbiologically induced calcite precipitation (MICP), which has been subjected to more developments, includes the potential to use the microbial enzyme and as a replacement for microbial cells itself. Mokhtar et al. [14] used B. sphaericus to produce biocementitious mortars; the study revealed that the compressive strength increased from 40 to $54 \mathrm{MPa}$ compared to $40.5 \mathrm{MPa}$ in traditional cement. The technoeconomic analysis conducted in the study estimated the

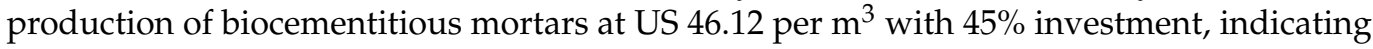
economic feasibility. Alshalif et al. [15] revealed that E. faecalis and B. cereus improved the compressive strength of bioconcrete by 23 and $14.2 \%$, respectively.

From another point of view, life cycle assessment (LCA) is widely used to determine the environmental impacts of any construction materials. For example, Balasbaneh and Sher [16] used LCA for different concrete construction techniques including prefabricated prefinished volumetric construction (PPVC), individual panel system (IPS), and on-site concrete (OSC) which are used for residential buildings in Malaysia based on human toxicity (HT), depletion of the ozone layer (OLD), terrestrial ecotoxicity (TE), greenhouse gas (GHG), and fossil depletion (FD). The study revealed that PPVC was more applicable among construction techniques with $6 \%$ of GHG, $2 \%$ of $\mathrm{FD}$, and $6 \%$ of OLD less than OSC. Huntzinger and Eatmon [17] used LCA to assess the environmental impacts of the production of blended cement (natural pozzolan), traditional Portland cement (TPC), and cement kiln dust (CKD). The study reported that blended cements were the safest for the environment; however, CKD recycling was associated with little environmental savings compared to TPC. Studies on the LCA of the concrete product performance and their application have been reported in the literature [18]. Thwe et al. [19] evaluated the LCA of the production of ordinary Portland cement (OPC) and the adverse effects on the environment. The study confirms the adverse environmental impacts of cement production; it was observed that calcination contributes $89 \%$ to climate change, $95 \%$ to acidification, and $97 \%$ to eutrophication. However, the adverse effects of cement manufacturing on climate change are well known.

To summarize the above, it can be seen that the environmental impacts for the generation of biocementitious materials have not been evaluated yet. In other words, the involved parameters of bio-concrete such as bacteria or fungi, urea, nutrition medium, as well as calcium chloride $\left(\mathrm{CaCl}_{2}\right)$ or nitrate $\left(\mathrm{CaNO}_{3}\right)$ are associated with environmental pollution and should be assessed using LCA. In particular, the environmental pollution is the result 
of the machine washing used in the production of biocementitious materials and the direct discharge of wastewater into the environment. Wastewater with urea is one of the main causes of the appearance of eutrophication in fresh and marine water [20], while $\mathrm{CaCl}_{2}$ and $\mathrm{CaNO}_{3}$ are classified as toxic substances [21]. The discharge of nutrients from wastewater generated from biocementitious materials into the natural water system provided a suitable medium for microbial growth in these waters [22]. As such, LCA is among the evaluation systems that might provide more detailed information on the effects of biocementitious materials on health risk, eutrophication in fresh and marine water, as well as marine ecotoxicity.

The purpose of the present article was to investigate the LCA of biocementitious material (mortar) production compared to the production of normal cementitious materials. The environmental impacts (EI) of the production process and management through their life cycle in terms of human health, terrestrial, fresh and marine ecotoxicity, as well as eutrophication in the natural water system were evaluated to evaluate its environmental sustainability. Solutions to overcome the environmental impacts of bio-cementitious materials were proposed.

\section{Materials and Methods}

\subsection{Experimental Setup}

The goal of the present work is to analyze the health and environmental risks associated with bio-cementitious materials which are generated by adding bacteria or fungi, molasses, and urea as well as nitrate during the concrete mixing. The waste generated from the generation of bio-cementitious materials has an impact on the environment and natural water sources which receive the wastewater generated from washing equipment's used in the cementitious materials. The risk is associated mainly with the biomaterials used, which might increase the eutrophication in the surface water. The LCA was conducted in line with ISO 21931-1:2010, which provides a general framework for improving the quality and comparability of methods of measuring the environmental performance of buildings and their associated external work. The diagram of the current work is presented in Figure 1a.

\subsection{Bibliometric Literature Review Methodology (BLR)}

Based on Scopus databases, a library analysis was used as a mechanical approach to assess current trends in cementitious and bio-cementitious materials research. The analysis was based on discussion of progress in biocement material research and sections of the literature requiring further research. VOSviewer (version 1.6.15) is a library analysis tool that helps visualize library maps. The keywords including ("bio-cementitious materials" OR "bio-cementitious"), ("bacteria" OR fungi"), ("microbiologically induced calcite precipitation" OR "bioconcrete"), AND (2010-2019) were separately used between "double line breaks" on the Scopus searching database for more accuracy. The keywords most commonly used in publications on bio-cementitious materials have been defined, and a list of bacteria and fungi used in bio-cementitious material publications has been obtained.

\subsection{Bio-Cementitious Materials Production Process}

The processes used in the generation of bio-cementitious materials are presented in Figure $1 \mathrm{~b}$, which was designed to produce 33,000 tons per year as described in a previous study [14]. The production process is started with the preparation of the bacterial or fungal suspension. The process is conducted using culture broth media such as nutrient broth or molasses in aerated fermentation tanks. The microbial (bacteria or fungi) biomass is separated from the culture media by centrifuge or spray drying and then subjected to freeze-drying for facility handling. The raw materials required for the production process are prepared separately and subjected to some processes such as sieving of sand, pretreatment of water, as well as preparation of the desired amounts of chemicals, urea, and $\mathrm{Ca}\left(\mathrm{NO}_{3}\right)_{2} \cdot 4 \mathrm{H}_{2} \mathrm{O}$ and should be dealt with precaution, for example by using gloves and masks, which are required to avoid the infection of the workers. The mixing of 
the raw materials with cement were conducted for $5 \mathrm{~min}$ before their use in the solid mortar template. The main concerns in the production process are the bio-cementitious materials, wastes, and wastewater generated by washing of the equipment used in the production process.

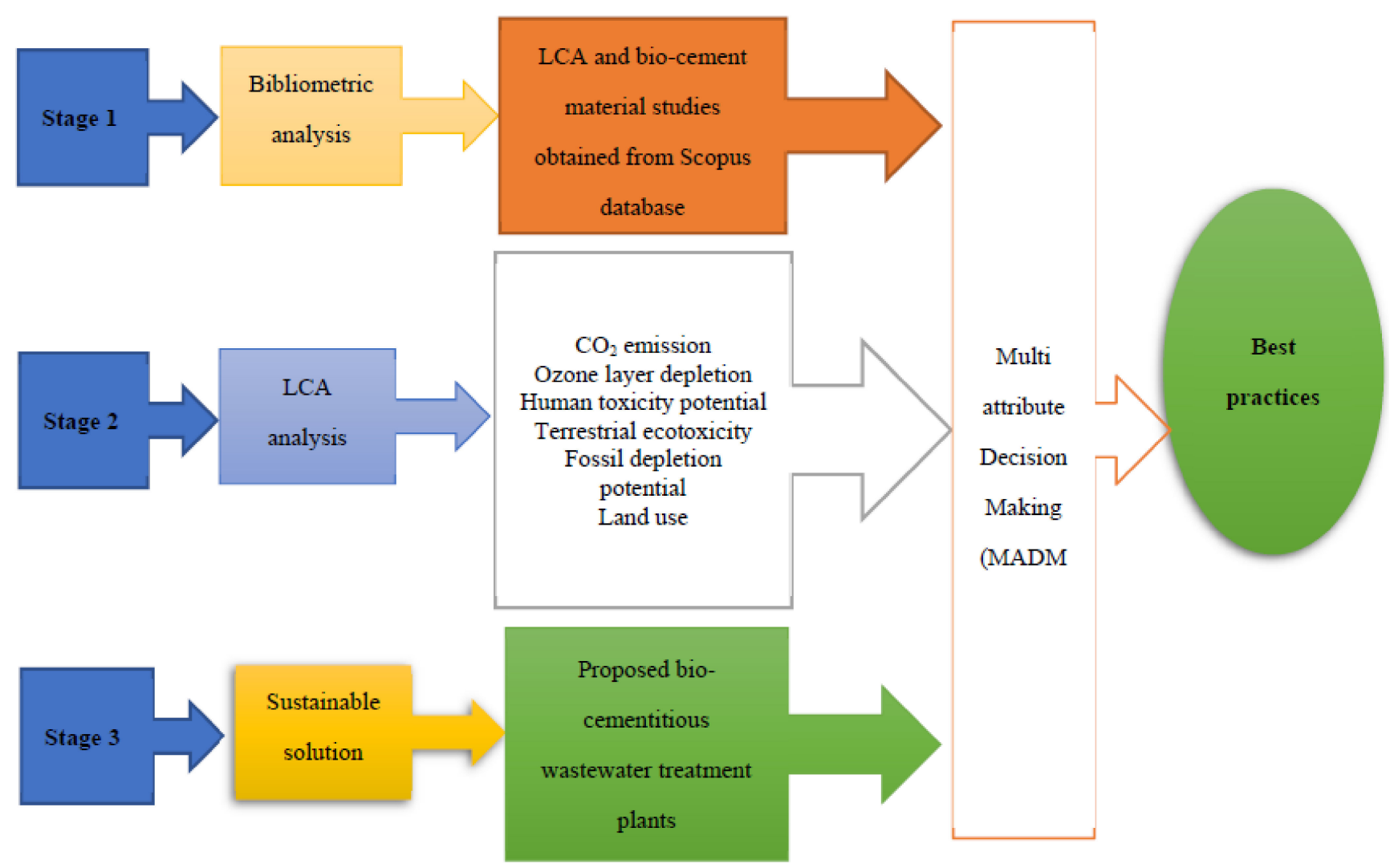

(a)

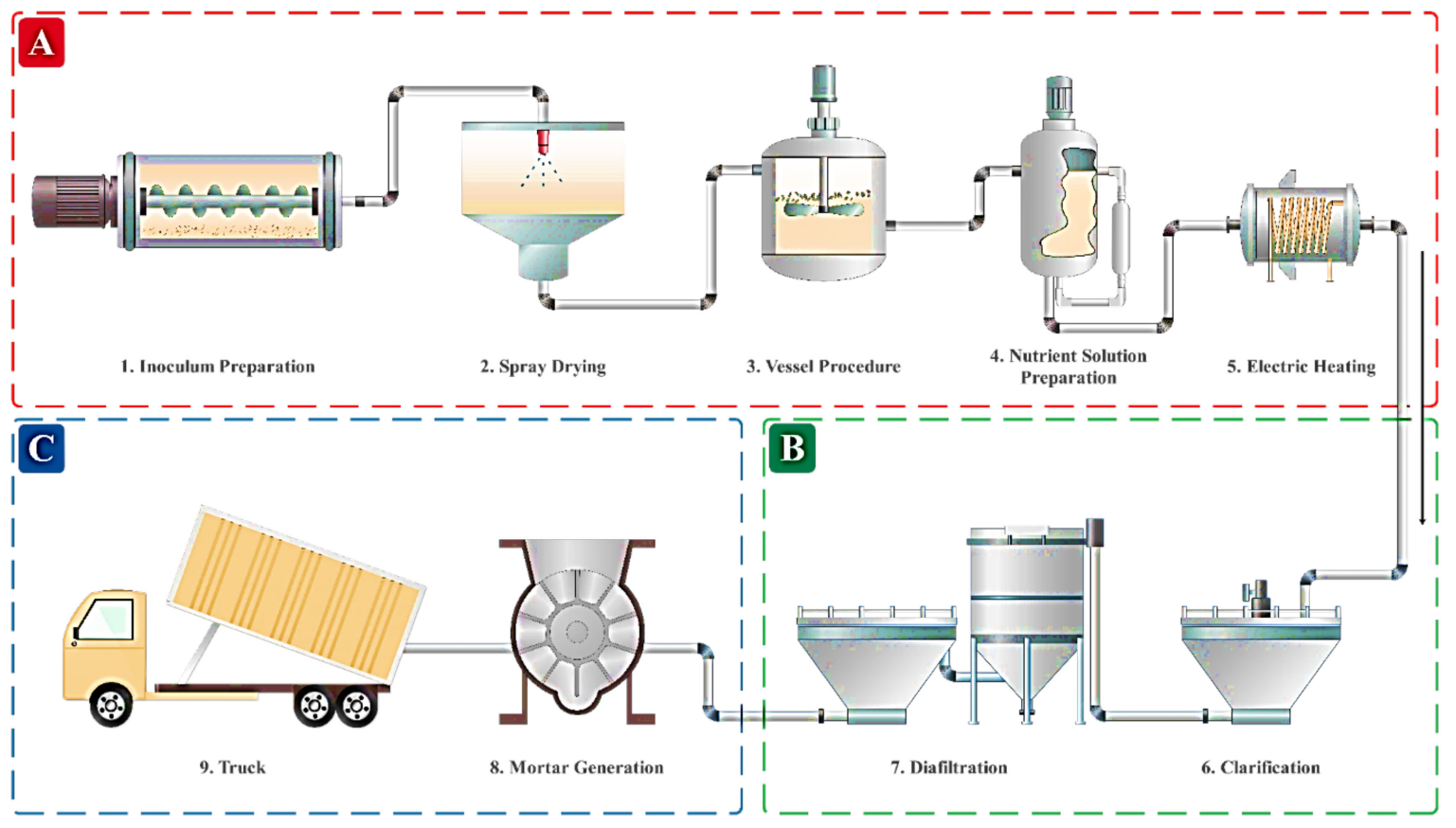

(b)

Figure 1. (a) Diagram of current work. (b) Production stages of the bio-cementitious materials. 


\subsection{LCA Analysis}

LCA was performed using SimaPro 8 (www.pre.nl, accessed on 18 September 2021) to evaluate the adverse impact of biocementitious materials during all stages of life cycle production including the extraction of raw materials used in production and the waste disposed of in the environment. The LCA of the biocementitious materials was compared with that of the cementitious materials without bacteria and chemical additives. In the LCA, the inputs and outputs of the production process were evaluated based on the negative effect of the production of biocementitious materials on terrestrial fresh and marine ecotoxicity, human health, as well as the eutrophication of surface water which could receive waste generated from the production process. The LCI database was used for all stages of production from microbe preparation, cementitious materials, manufacturing, maintenance, transportation, and end of life, including final disposal of waste into the environment.

\subsection{Life Cycle Inventory (LCI) Analysis of Raw Materials and Products}

The data used to model the biocementitious materials production process chain, such as the quantities required for the production process, were taken from our previous study [14]. The quantities of materials required for the process are 1105.5 tons of nutrient solution, 3564 tons of bacterial suspension, 47,520 tons of sand, 14,256 tons of cement, 3564 tons of water, $7128 \mathrm{~kg}$ of freeze-dried bacterial cells, 356,612.9 kg of urea, 713,225.8 kg of $\mathrm{Ca}\left(\mathrm{NO}_{3}\right)_{2} \cdot 4 \mathrm{H}_{2} \mathrm{O}$, and $713,225.8 \mathrm{~kg}$ of diatomaceous earth which is used to support the bacterial colonization in biocementitious materials. These chemicals and materials, as well as energy resources, were used from the inventory list of SimaPro 8. The transport of raw materials and products, as well as the distances, were estimated based on specific materials suppliers and communication with a local manufacturing company for cementitious materials. The role of electricity in global warming is generated from the source of energy. In Malaysia, $46 \%$ of the electricity is generated from coal, $39.7 \%$ from national gas, and $13.2 \%$ from hydropower [23].

\subsection{Life Cycle Impact Assessment (LCIA)}

The LCA for biocementitious materials was applied in this study and the inputs from raw materials, transportation, energy consumption, waste release, and wastewater must be considered as a benchmark for both types of cementitious materials. The processes involved are mixing, shaping, and curing process. ReCiPe 2016 is a major improvement over ReCiPe 2008 and the predecessors CML 2000 and Ecoindicator 99. The methodology is regularly updated to include new data and new research. The LCA analysis was performed with the ReCipe 2016 end point E world/2010 (E/A).

\section{Results and Discussion}

\subsection{Bibliometric Analysis of Previous Studies on Cementitious Materials Production}

The distribution of cementitious materials production in the world is presented in Figure 2, which was carried out based on the analysis of 2000 articles from the Scopus database (Suppl. 1). It was noted that $19.04 \%$ of the total production was in China, followed by $14.9 \%$ in India, $7.98 \%$ in USA, $6.91 \%$ in The Netherlands, $5.37 \%$ in Belgium, and $4 \%$ in Malaysia. Analysis of the studies in the literature was downloaded from the Scopus database (Suppl. 2) using bibliometric analysis and has revealed many microorganisms that have been used in the production of biocementitious materials (Figure 3). More than $95 \%$ of the microorganisms used belong to bacteria and included aerobic and facultative aerobic bacteria such as Bacillus spp., B. cereus, B. halodurans, B. megaterium, B. pasteurii, B. pseudofirmus, B. sphaericus, B. subtilis, Pseudomonas aeruginosa, spore-forming bacteria, Sporosarcina pasteurii, B. tequilensis, and Enterococcus faecalis, while $4.7 \%$ of the studies used fungal species such as Phanerochaete chrysosporium, Rhizopus oryzae, Aspergillus nidulans, A. oryzae, A. terreus, and Trichoderma reesei [24,25]. Analysis of studies from the Scopus database revealed that LCA has been used to evaluate cement production, carbon emissions, 
carbon footprint, greenhouse gases, and sustainable construction in cement manufacturing (Figure 4).

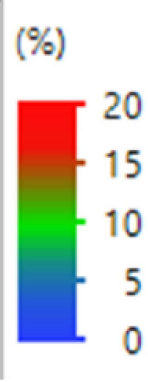

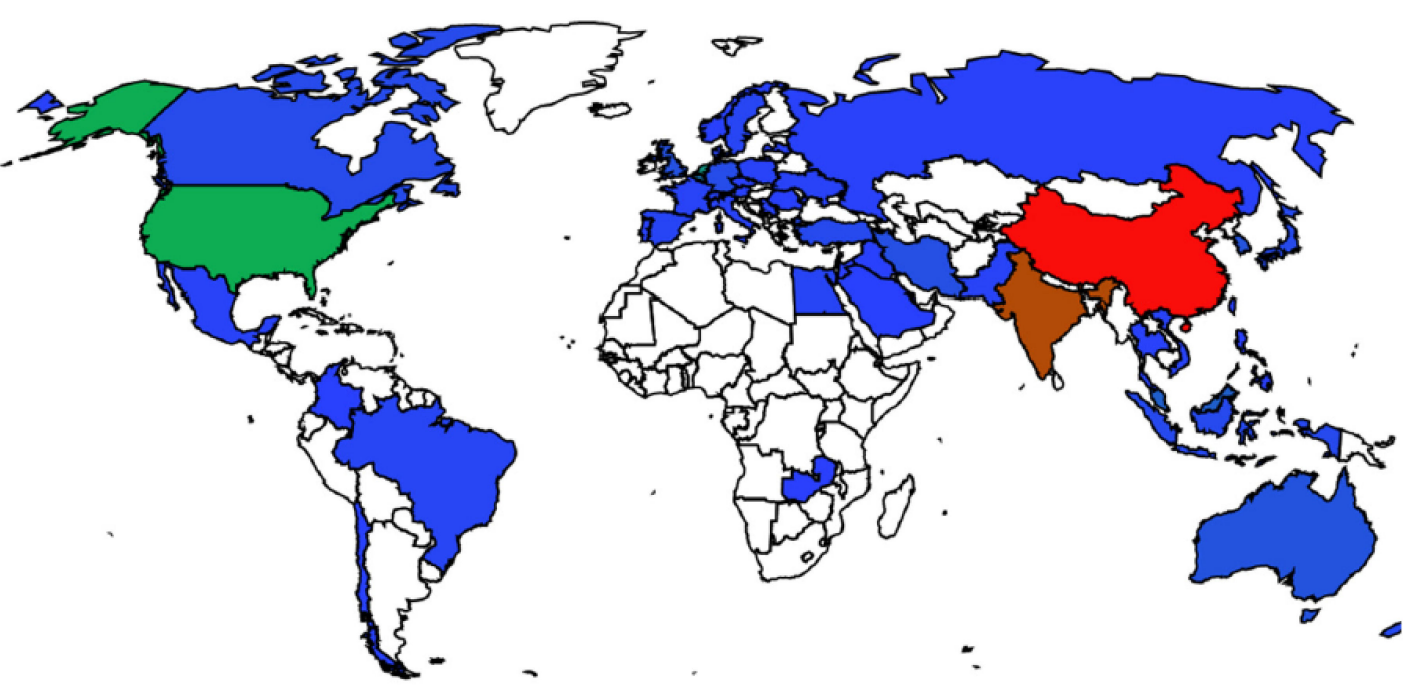

Figure 2. Distribution of bio-cementitious materials production in the world based on the data analysis for 2000 studies from Scopus data base.

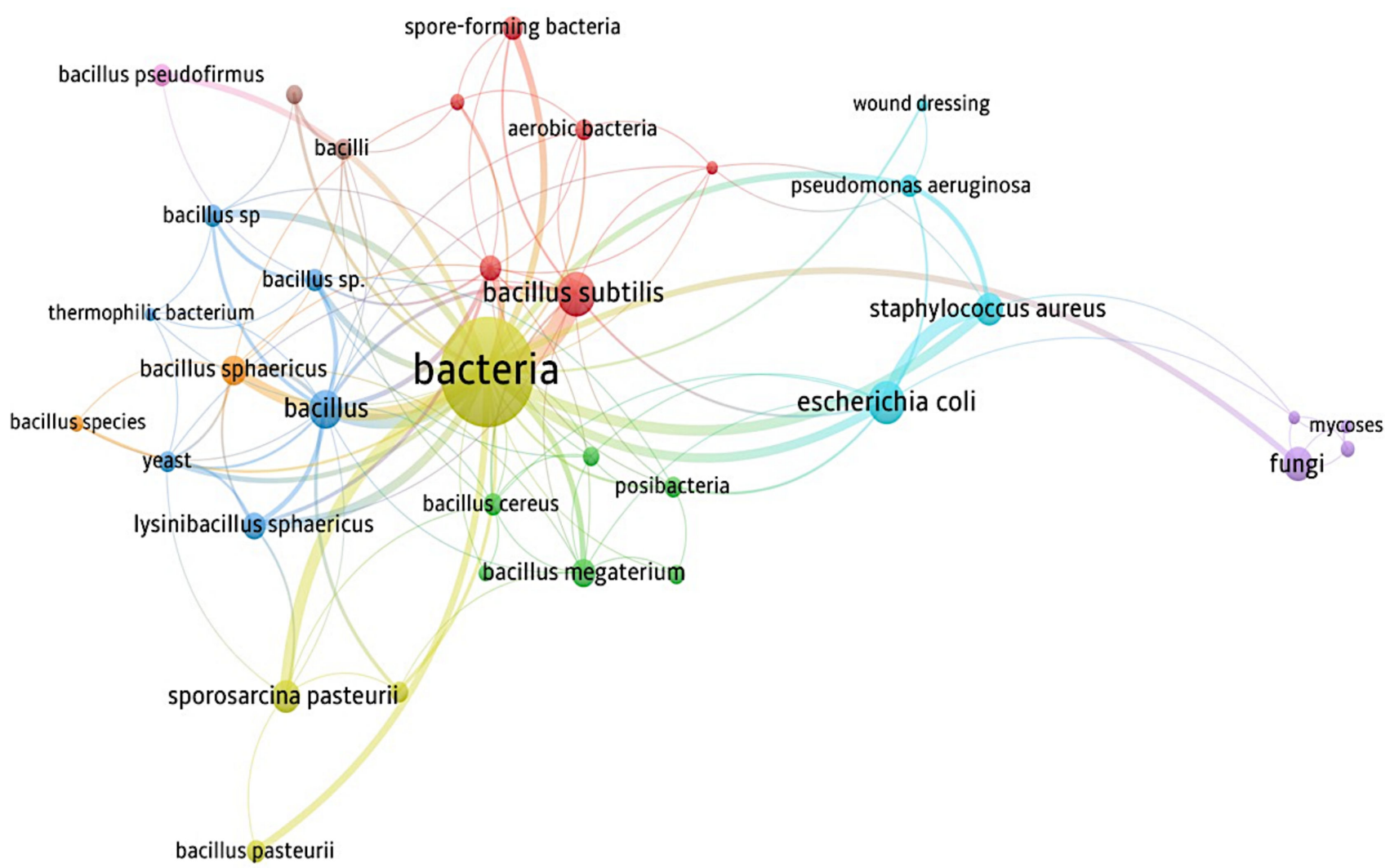

Figure 3. Most common bacteria used in the bio-cementitious materials production in the world based on the data analysis for 275 studies from Scopus data base. 


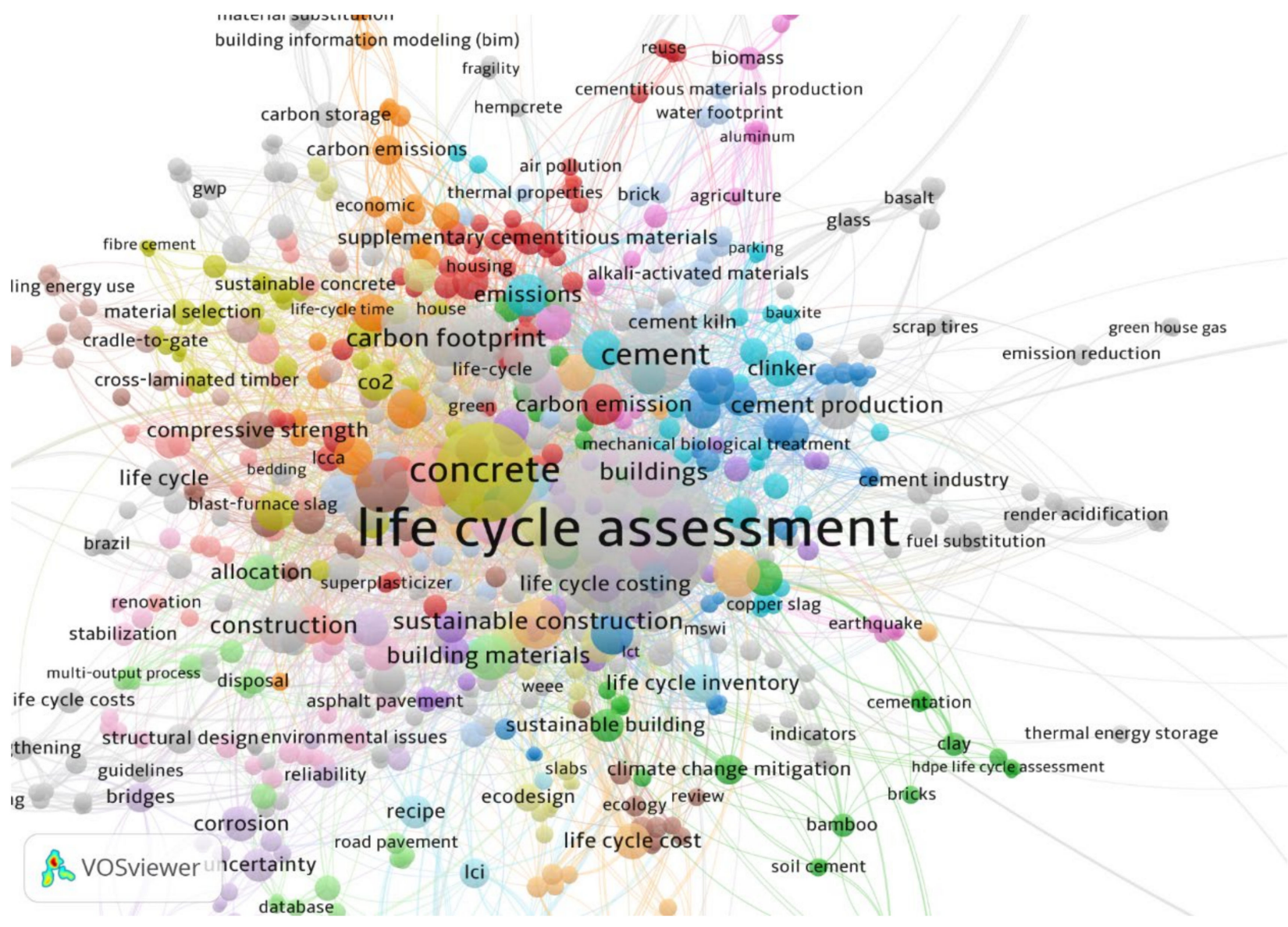

Figure 4. LCA studies on different types of construction materials based on the data analysis for studies from Scopus database.

\subsection{LCA Characterization}

The characterization analysis for $1 \mathrm{~kg}$ of cementitious material production is presented in Figure 5. The figure describes the health risk and environmental impacts associated with the production of biocementitious materials compared to the traditional cementitious materials. It was observed that among the raw materials used in the production process, cement materials contribute by $82.8894 \%$ to global warming, $87.2489 \%$ to human health through ozone formation, $71.4572 \%$ to fine matter formatter, $87.09 \%$ to the effects of terrestrial ecosystems through ozone formation, $76.7733 \%$ to terrestrial acidification, $79.652 \%$ to terrestrial ecotoxicity effects, $70.1364 \%$ to marine ecotoxicity, 61.705 to human carcinogenic toxicity, 61.0239 to land use, $85.9422 \%$ to freshwater eutrophication, and $30.4805 \%$ to marine eutrophication. Compared to the traditional production of cementitious materials, it was observed that among the raw materials used (cement, sand, water), cement materials contribute more than $98 \%$ to the parameters that include global warming. The negative effects of raw cement materials on the environment are associated with the generation of cement in the manufacture of cement and not with the production of cementitious materials. The role of cement manufacturing in air pollution and environmental impacts has been reported by many authors in the literature. Five percent (5\%) of global anthropogenic $\mathrm{CO}_{2}$ emissions have been reported to be generated from the cement industry due to raw materials such as limestone, clay, calcareous marl, and production stages such as burning (fossil) fuels used in the production process [26]. The matter of the particles is the most visible pollutants that are generated from the cement industry. Dust is also generated during the production and transport of concrete. However, the use of water sprays effectively contributes to emission reduction [27]. 

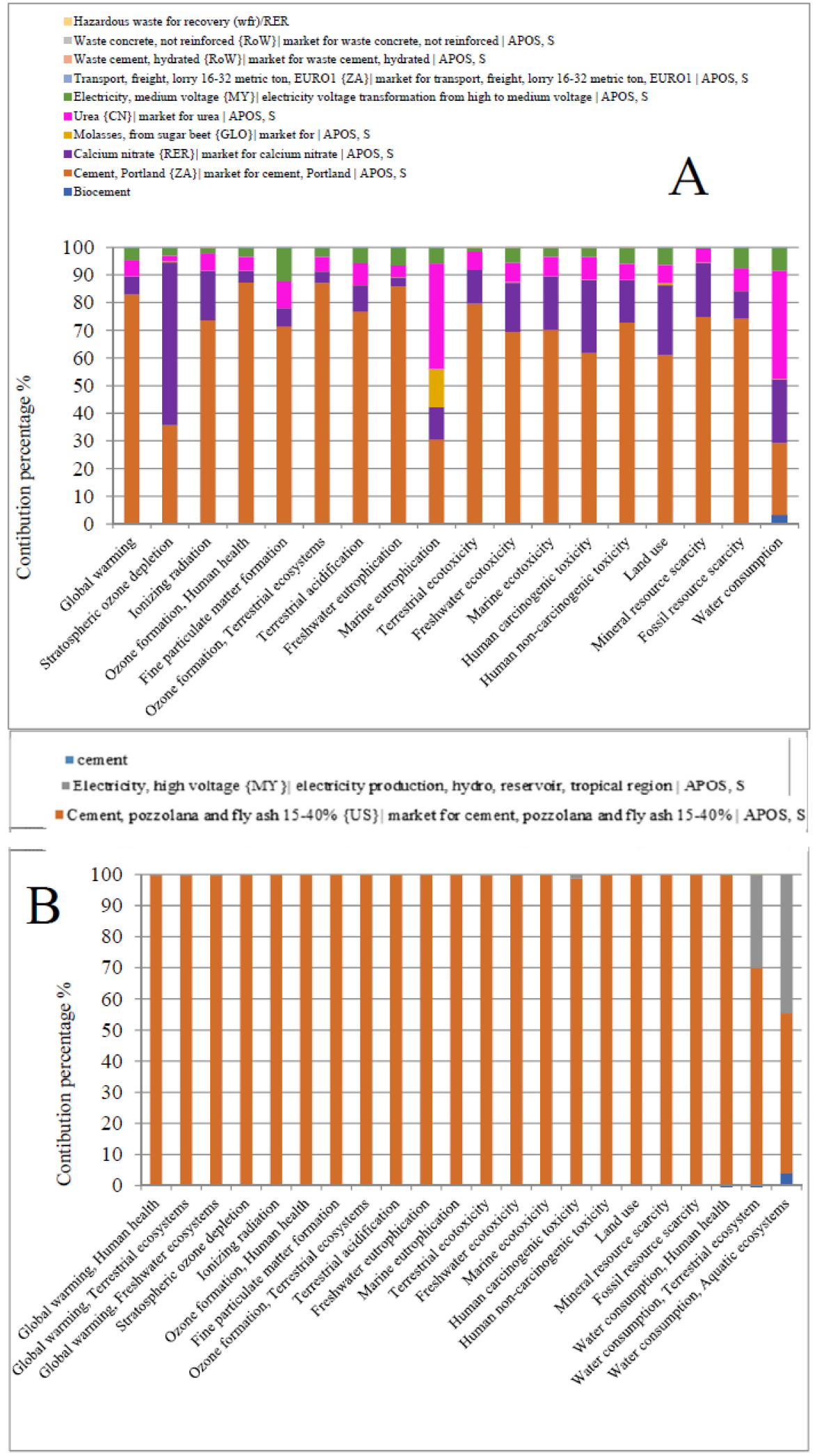

Figure 5. Health risk and environmental impacts associated with the production of biocementitious materials compared to the traditional cementitious materials as determined using ReCiPe 2016 Method, end point (E) V 1.05, world 2010 (E/A); (A) bio-cementitious materials; (B) cementitious materials. 
The LCA of the other raw materials used in the production of biocementitious materials revealed that $\mathrm{Ca}\left(\mathrm{NO}_{3}\right)_{2} \cdot 4 \mathrm{H}_{2} \mathrm{O}$ contributes by $58.885 \%$ to ozone depletion, $6.569 \%$ to global warming, $4.191 \%$ to human health through ozone formation, $6.567 \%$ to fine matter formatter, $4.42 \%$ to the effects of terrestrial ecosystems through ozone formation, $9.53 \%$ to terrestrial acidification, $12.102 \%$ to terrestrial ecotoxicity effects, $19.348 \%$ to marine ecotoxicity, 26.527 to human carcinogenic toxicity, 25.27 in land use, 3.191\% in freshwater eutrophication, and $11.768 \%$ to marine eutrophication. Urea contributes $38.1538 \%$ in marine eutrophication, $5.9118 \%$ in global warming, $6.3191 \%$ in ionization radiation, $5.1307 \%$ in human health through ozone formation, $9.5344 \%$ in fine particular matter formatter, 5.3107\% in terrestrial ecosystem effects through ozone formation, $7.9307 \%$ in terrestrial acidification, $6.5829 \%$ in terrestrial ecotoxicity effects, $7.0593 \%$ in marine ecotoxicity, $8.1824 \%$ in human carcinogenic toxicity, 6.643 in land use, and 4.2556\% in freshwater eutrophication. Molasses contributes by $13.779 \%$ to marine eutrophication, while molasses has no role in the effects on other parameters. The high concentration of urea discharged from wastewater generated from the cleaning of equipment used in biocement production is associated with the occurrence of harmful algae blooms due to eutrophication in the natural water system [28]. Molasses effectively contributes to the diversity of marine life due to the absorption of oxygen in water by liquid sugar. Molasses also contributes to the appearance of algae blooms and the growth of pathogenic bacteria [29].

The electricity used in the production of biocementitious materials contributes by $4.6113 \%$ to global warming, $2.9895 \%$ to ozone radiation, $3.3938 \%$ to human health through ozone formation, $12.3808 \%$ to fine matter formatter, $3.3952 \%$ to the effects of terrestrial ecosystems through ozone formation, $5.6533 \%$ to terrestrial acidification, $1.593 \%$ to terrestrial ecotoxicity effects, $3.3748 \%$ to marine ecotoxicity, $3.5414 \%$ to human carcinogenic toxicity, 6.384 to land use, $5.5948 \%$ to freshwater eutrophication, and $5.827 \%$ to marine eutrophication.

Based on the LCA analysis, it can be indicated that the main risk associated with the biocementitious materials productions lies in the using of bacteria, molasses, urea, and nitrate which contribute to the increasing of environmental pollution.

\subsection{Damage Assessment of Bio-Cementitious Materials Production}

The damage assessment of the human health ecosystem and resources as a result of the raw materials used in the production of bio-cementitious materials is presented in Figure 6A,B. The results revealed that cement contributed by $74.9299 \%$ in the human health damage, $79.3672 \%$ in ecosystem damage, while contributed by $60.5397 \%$ in the resources (Figure 6A). The $\mathrm{Ca}\left(\mathrm{NO}_{3}\right)_{2} \cdot 4 \mathrm{H}_{2} \mathrm{O}$ contributes by $13.5489 \%$ in human health damage, $9.9967 \%$ in ecosystem damage, and by $20.8058 \%$ in resources, while urea contributes by $6.5126 \%$ in human health damage, $5.9169 \%$ in ecosystem damage, while contributing by $9.346 \%$ in resources. In contrast, electricity contributes by $4.9842 \%$ in human health damage, $4.6898 \%$ in ecosystem damage, while contributing by $9.2556 \%$ in resources. In comparison, damage assessment of the human health ecosystem and resources as a result of the raw materials used in the production of cementitious materials resulted from the raw cement materials (Figure 6B). The bio-cementitious materials products have no effect on the investigated parameters; these findings indicated that the main issues in the production of bio-cementitious materials lie in the raw materials used, while the product is safe for handling and use in the construction building. 
- Calcium nitrate $\{R E R\} \mid$ market for calcium nitrate $\mid$ APOS, S

- Cement, Portland $\{Z A\} \mid$ market for cement, Portland $\mid$ APOS, S

Electricity, medium voltage $\{\mathrm{MY}\} \mid$ electricity voltage transformation from high to medium voltage $\mid \mathrm{APOS}, \mathrm{S}$

-Urea $\{\mathrm{CN}\} \mid$ market for urea $\mid \mathrm{APOS}, \mathrm{S}$

A

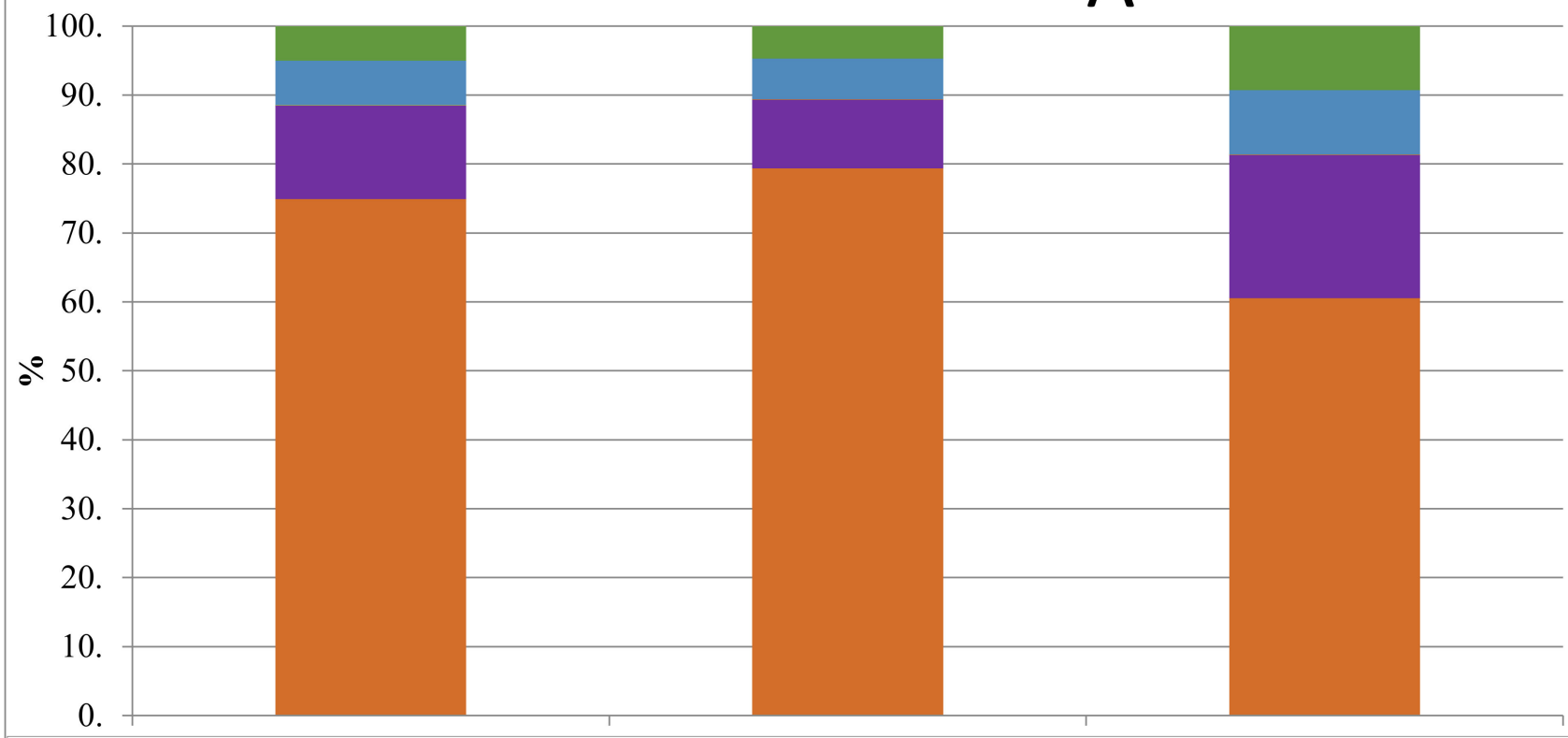

- Cement, pozzolana and fly ash $15-40 \%$ \{US\}| market for cement, pozzol ana and fly ash $15-40 \% \mid$ APOS, S

n Wastewater from ceramic production $\{\mathrm{CH}\} \mid$ market for wastewater from ceramic production $\mid$ APOS, S

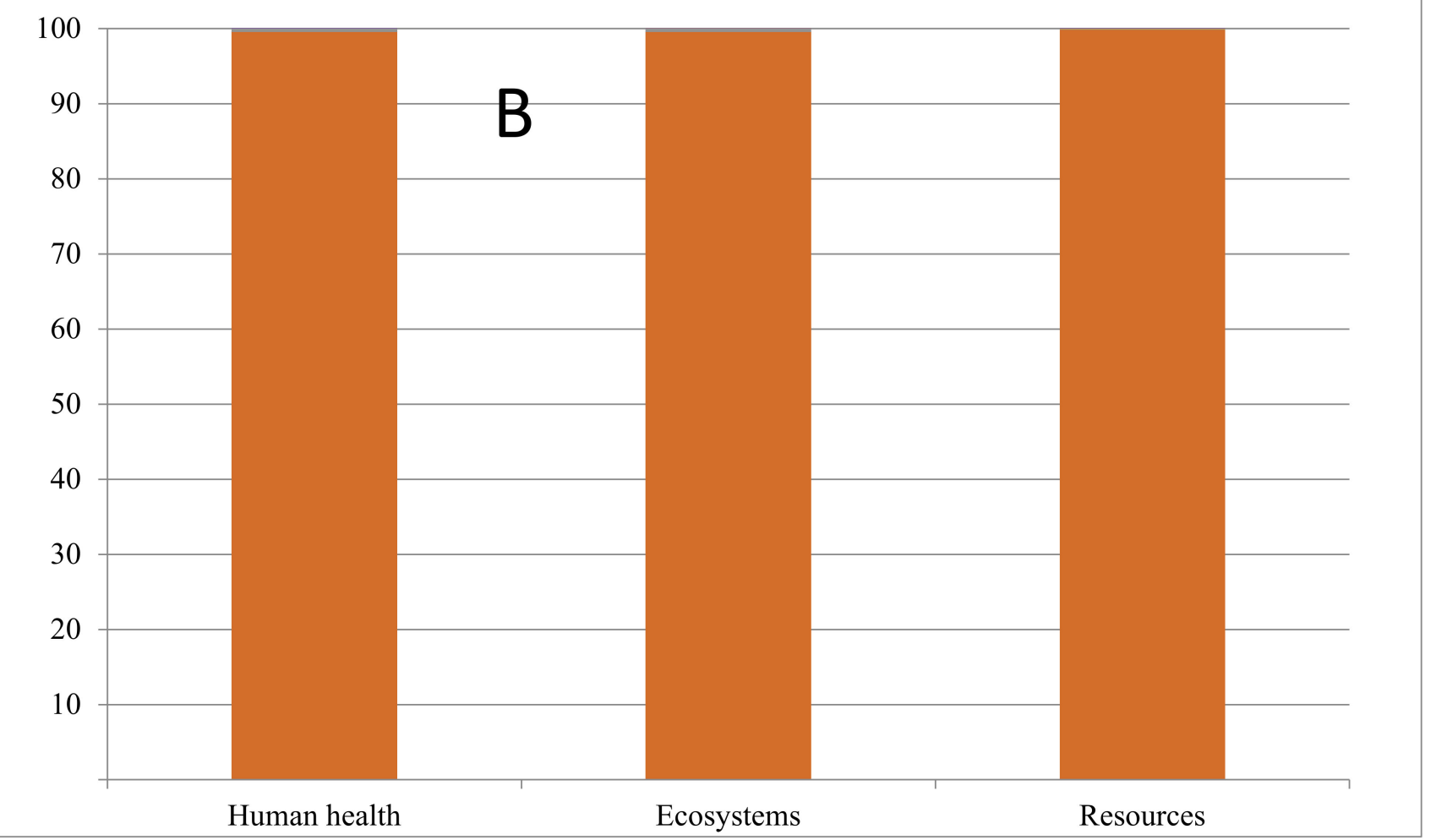

Figure 6. Damage assessment for one $\mathrm{kg}$ of the cementitious materials production as determined using ReCiPe 2016 Method, end point (E) V 1.05, world 2010 (E/A); (A) bio-cementitious materials; (B) cementitious materials. 
The human health damage of cement lies in the effect on the skin, eye contact, and inhalation. These effects depend on the level and duration of exposure and occur as a result of the presence of calcium oxide, crystalline silica, and chromium which have a corrosive effect on the human tissue and lungs and might cause allergic reactions [30]. The energy consumption of concrete production is the biggest environmental concern, since the process is among the most energy intensive compared to other industries. The main issue is related to the direct fuel which is used for transportation of raw materials, mining, and production process of concrete [27]. The urea discharged with wastewater from bio-cementitious materials production is hydrolyzed to ammonium since urea is a nonpolar molecule and is not stable in the environment. The ammonia is oxidized to nitrate and then subjected to chemical reactions under anaerobic conditions to form $\mathrm{N}_{2}, \mathrm{~N}_{2} \mathrm{O}$, or $\mathrm{NO}_{\mathrm{x}}$ gases which play an important role in the ozone layer depletion [31].

\subsection{Sustainable Solutions}

The high amount of clean water used in construction industry has always attracted the attention of researchers and engineers due to its high quality [32]. Several studies have been conducted on managing and reusing partially treated wastewater for concrete cement mixtures, which showed acceptable results compared to clean water [33]. Although many studies have been performed in concrete cement recycling, there is a gap in finding sustainable techniques or strategies on or off-site to deal with cementitious mixture tools. To minimize the environmental and real impacts of the production of biocementitious materials, the wastewater generated from the washing of equipment used in the production process should be subjected to a treatment process to remove the urea and molasses residues as well as calcium nitrate before the final disposal into the environment. The wastewater treatment process might include the primary sedimentation in which bio-cementitious materials are removed and recycled. In the current work, a sustainable strategy was designed to fill this gap and highlight new sources of various recycled materials and water that can be used in construction and other industries. Figure 7 illustrates an innovative technique to take advantage of contaminants produced by the equipment of construction industries that are often not appropriately handled. The technique aims to treat the wastewater produced from cleaning concrete equipment and reuse it sustainably to clean the equipment again. The processing produces primary and secondary elements that are used in various fields. The concrete products removed from equipment represent the primary materials as they are separated from the water and deposited in the sedimentation tank depending on their weight and cementitious characteristics that allow them to harden in the stagnant state (Figure 7).

The separated water is transferred to the filtered water tank through the screen to remove the small particles, while the precipitated products are collected to be reused in the construction industry. Fraile-Garcia et al. [34] have confirmed the feasibility of using cement-concrete wastes as an artificial aggregate and recycled material in fresh concrete. The separated water usually contains various elements, including calcium nitrate, urea, molasses, and bacteria, which require an additional process. Therefore, these effluents should be subjected to phycoremediation with microalgae since the urea is hydrolyzed into ammonium and ammonia, which is difficult to remove by the traditional primary and secondary treatment process. The treated effluents generated from the phycoremediation might be discharged or reused for the washing of the equipment used in the production process. The microalgae biomass might be separated and then used as an inoculum for the next phycoremediation process. The microalgae remove heavy metals and residual contaminants through various mechanisms and pathways, such as the employment of urease enzymes with nickel catalysis to hydrolyze urea (Figure 8) [35]. 


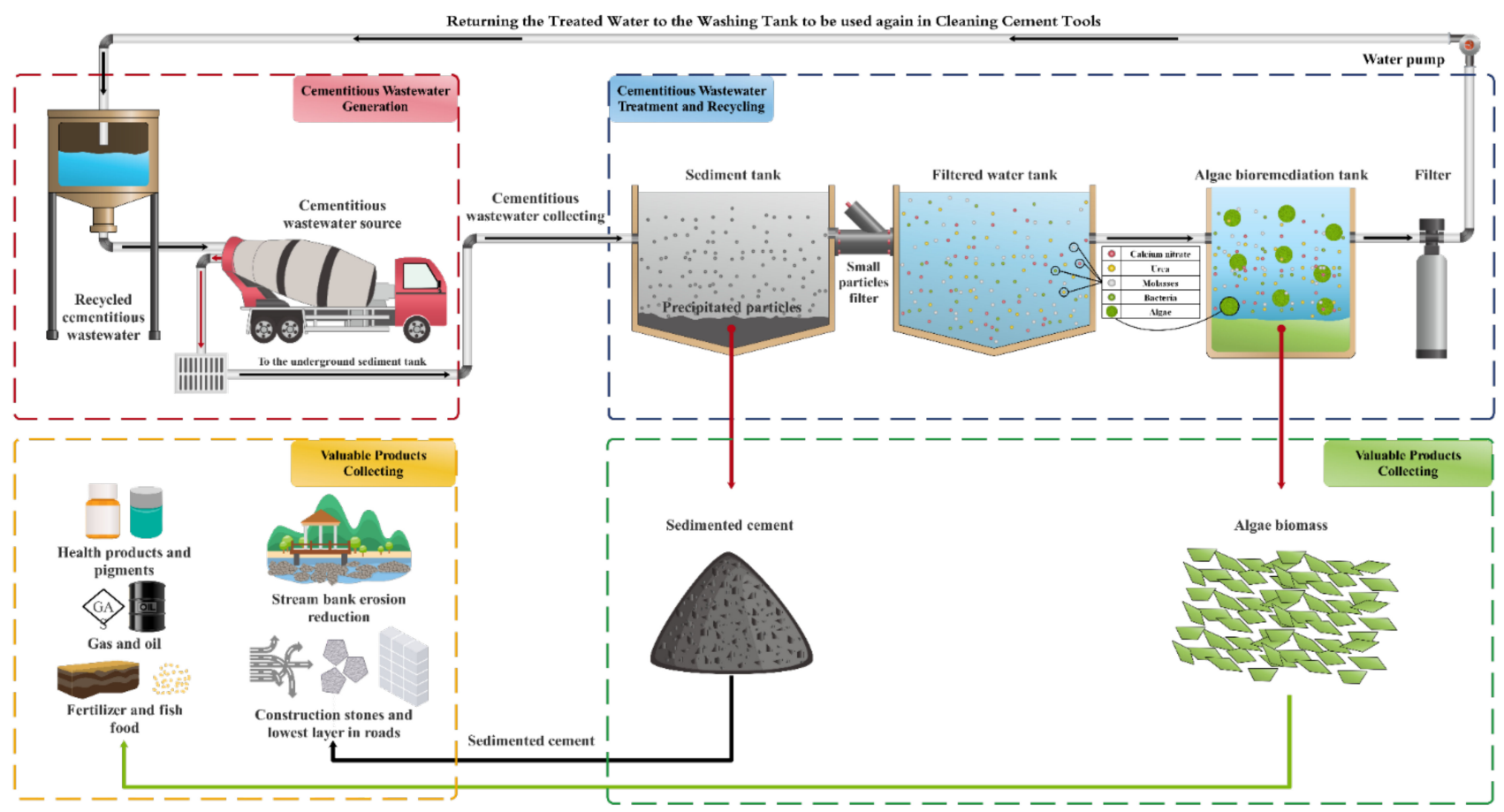

Figure 7. Proposed biocementitious wastewater treatment plant.

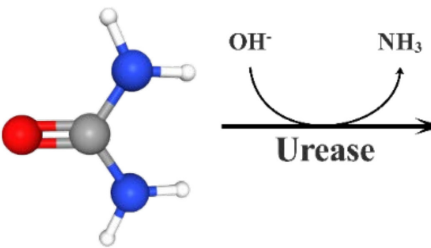

Urea

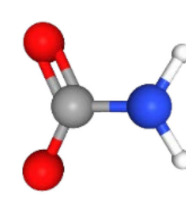

Carbamate

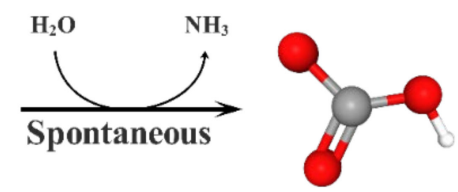

Bicarbonate

Figure 8. Hydrolysis of urea by microorganisms.

The generated algal biomass contains valuable products, including polyunsaturated fatty acids, lipids, dyes, antioxidants, poisons, and many other products that can be used to industrialize biofuels, medicine, proteins, fish food, and many other uses [36]. Reverse osmosis ( $\mathrm{RO}$ ) filter or any nano filter is used after the microalgae tank to remove the released algae cells or toxic and remaining elements. The filtered water after this stage will be pumped directly to the recycled wastewater tank to be used later in cleaning the cementitious equipment. The current technology is distinguished from other technologies by its flexibility in developing and changing, such as adding a sensor system that simulates the entire operation and makes the system self-operated, changing the tank to conduct other purification operations, and changing the locations of tanks to dispense with pumps and other modifications. Moreover, this technique can be used for various industrial pretreatment systems to keep up with the global strict environmental laws.

\section{Conclusions}

LCA of the biocementitious materials using ReCiPe 2016 Method, end point (E) V 1.05, world 2010 (E/A) was successfully evaluated in terms of the health and environmental risk associated with the production of bio-cementitious materials. The results revealed that the bio-cementitious materials production has more environmental impact compared to the traditional cementitious materials. This is due to the presence of organic materials such as urea and molasses and inorganic chemicals such as calcium nitrate. The presence of the bacterial might represent a risk for the worker. However, in most of the studies the bacterial species used are non-pathogenic. Based on the LCA, the main contribution in global 
warming and human health is the cement materials ( $82.88 \%$ and $87.24 \%$ respectively) as well as $85.94 \%$ in freshwater eutrophication, while $\mathrm{Ca}\left(\mathrm{NO}_{3}\right)_{2} \cdot 4 \mathrm{H}_{2} \mathrm{O}$ contributes by $58.88 \%$ in the ozone depletion, urea contributes by $38.15 \%$ in the marine eutrophication and $5.25 \%$ in the freshwater eutrophication in the eutrophication, and the molasses contributes by $13.77 \%$ in the marine eutrophication. The application of a treatment process for the biocementitious wastewater might minimize the environmental impacts. The bio-cementitious wastes can be reused while the treated effluents can be reused for the washing process. The treatment process using phycoremediation process will provide less polluted effluents for safe disposal. Therefore, the present study has highlighted the main issues related to the bio-cementitious production and suggested a sustainable solution foe minimize the health and environmental impacts for bio-cementitious. However, the suggested wastewater treatment plant needs more studies to confirm the applicability to remove organic pollutants from the bio-cementitious wastewater.

Author Contributions: Conceptualization, A.A.A.-G.; methodology, A.A.A.-G. and A.T.B.; software, A.A.A.-G. and A.T.B.; validation, N.O. and M.I.J.; formal analysis, Z.A.M. and H.A.A.; investigation, E.A.N. and A.A.A.-G.; resources, Z.A.M.; writing-original draft preparation, A.A.A.-G. and E.A.N.; writing-review and editing, A.T.B., N.O., M.I.J., H.A.A., W.A.A.-K. and N.M.; visualization, A.A.A.G., H.A.A. and W.A.A.-K.; supervision, M.I.J. and N.O.; project administration, A.A.A.-G.; funding acquisition, Z.A.M. All authors have read and agreed to the published version of the manuscript.

Funding: The current work was funded by Universiti Tun Hussein Onn Malaysia through Tier 1 Grant H743.

\section{Institutional Review Board Statement: Not applicable.}

Informed Consent Statement: Not applicable.

Data Availability Statement: The data presented in this study are available on request from the corresponding author. The data are not publicly available due to data privacy.

Acknowledgments: The authors would like to acknowledge the support of Prince Sultan University for paying the Article Processing Charges (APC) of the publication.

Conflicts of Interest: The authors declare that they have no conflict of interest.

\section{References}

1. Gartner, E.M.; Macphee, D.E. A physico-chemical basis for novel cementitious binders. Cem. Concr. Res. 2011, 41, 736-749. [CrossRef]

2. Saleh, H.M.; Eskander, S.B. Impact of water flooding on hard cement-recycled polystyrene composite immobilizing radioactive sulfate waste simulate. Constr. Build. Mater. 2019, 222, 522-530. [CrossRef]

3. Saleh, H.M.; El-Sheikh, S.M.; Elshereafy, E.E.; Essa, A.K. Performance of cement-slag-titanate nanofibers composite immobilized radioactive waste solution through frost and flooding events. Constr. Build. Mater. 2019, 223, 221-232. [CrossRef]

4. Szilagyi, H.; Baeră, C.; Hegyi, A.; Lăzărescu, A. Romanian resources of waste and industrial by-products as additions for cementitious mixtures. Int. Multidiscip. Sci. GeoConference SGEM 2018, 18, 325-332.

5. Fapohunda, C.; Akinbile, B.; Shittu, A. Structure and properties of mortar and concrete with rice husk ash as partial replacement of ordinary Portland cement-A review. Int. J. Sustain. Built Environ. 2017, 6, 675-692. [CrossRef]

6. Akinyemi, B.A.; Dai, C. Development of banana fibers and wood bottom ash modified cement mortars. Constr. Build. Mater. 2020, 241, 118041. [CrossRef]

7. Al-Kutti, W.; Nasir, M.; Johari, M.A.M.; Islam, A.B.M.S.; Manda, A.A.; Blaisi, N. An overview and experimental study on hybrid binders containing date palm ash, fly ash, OPC and activator composites. Constr. Build. Mater. 2018, 159, 567-577. [CrossRef]

8. Nasr, M.S.; Shubbar, A.A.; Abed, Z.A.A.R.; Ibrahim, M.S. Properties of eco-friendly cement mortar contained recycled materials from different sources. J. Build. Eng. 2020, 31, 101444. [CrossRef]

9. Algaifi, H.A.; Bakar, S.A.; Sam, A.R.M.; Ismail, M.; Abidin, A.R.Z.; Shahir, S.; Altowayti, W.A.H. Insight into the role of microbial calcium carbonate and the factors involved in self-healing concrete. Constr. Build. Mater. 2020, 254, 119258. [CrossRef]

10. Algaifi, H.A.; Bakar, S.A.; Alyousef, R.; Sam, A.R.M.; Ibrahim, M.W.; Shahidan, S.; Ibrahim, M.; Salami, B.A. Bio-inspired self-healing of concrete cracks using new B. pseudomycoides species. J. Mater. Res. Technol. 2021, 12, 967-981. [CrossRef]

11. Khan, A.N.; Magar, R.B.; Chore, H.S. Efficiency factor of supplementary cementitious materials: A state of art. Int. J. Optim. Civ. Eng. 2018, 8, 247-253.

12. Wood, J.G.M. Structural aspects of repair. In Concrete Repair: A Practical Guide; Grantham, M.C., Ed.; Routledge: London, UK; Taylor \& Francis: New York, NY, USA, 2011; Chapter 3; pp. 74-89. 
13. Rosewitz, J.A.; Wang, S.; Scarlata, S.F.; Rahbar, N. An enzymatic self-healing cementitious material. Appl. Mater. Today 2021, 23, 101035. [CrossRef]

14. Mokhtar, N.; Johari, M.A.M.; Tajarudin, H.A.; Al-Gheethi, A.A.; Algaifi, H.A. A sustainable enhancement of bio-cement using immobilised Bacillus sphaericus: Optimization, microstructural properties, and techno-economic analysis for a cleaner production of bio-cementitious mortars. J. Clean. Prod. 2021, 318, 128470. [CrossRef]

15. Alshalif, A.F.; Juki, M.I.; Othman, N.; Al-Gheethi, A.A.; Khalid, F.S. Improvement of mechanical properties of bio-concrete using Enterococcus faecalis and Bacillus cereus. Environ. Eng. Res. 2019, 24, 630-637. [CrossRef]

16. Balasbaneh, A.T.; Sher, W. Life cycle sustainability assessment analysis of different concrete construction techniques for residential building in Malaysia. Int. J. Life Cycle Assess. 2021, 26, 1301-1318. [CrossRef]

17. Huntzinger, D.N.; Eatmon, T.D. A life-cycle assessment of Portland cement manufacturing: Comparing the traditional process with alternative technologies. J. Clean. Prod. 2009, 17, 668-675. [CrossRef]

18. Lippiatt, B.; Ahmad, S. May Measuring the life-cycle environmental and economic performance of concrete: The BEES approach In Proceedings of the International Workshop on Sustainable Development and Concrete Technology, Beijing, China, 20-21 May 2004; Volume 2004, pp. 213-230.

19. Thwe, E.; Khatiwada, D.; Gasparatos, A. Life cycle assessment of a cement plant in Naypyitaw, Myanmar. Clean. Environ. Syst. 2021, 2, 100007. [CrossRef]

20. Zhang, P.; Peng, C.H.; Zhang, J.B.; Zou, Z.B.; Shi, Y.Z.; Zhao, L.R.; Zhao, H. Spatiotemporal urea distribution, sources, and indication of DON bioavailability in Zhanjiang Bay, China. Water 2020, 12, 633. [CrossRef]

21. Hewlett, P.; Liska, M. (Eds.) Lea's Chemistry of Cement and Concrete; Butterworth-Heinemann: Oxford, UK, 2019. Available online: https:/ / www.elsevier.com/books/leas-chemistry-of-cement-and-concrete/hewlett/978-0-7506-6256-7 (accessed on 24 December 2021).

22. Farahani, S.S.; Asoodar, M.A. Life cycle environmental impacts of bioethanol production from sugarcane molasses in Iran. Environ. Sci. Pollut. 2017, 24, 22547-22556. [CrossRef]

23. DOSM. Overview Electricity Sector in Malaysia, Department of Statistics Malaysia. 2018. Available online: www.dosm.gov.my (accessed on 18 September 2021).

24. Luo, J.; Chen, X.; Crump, J.; Zhou, H.; Davies, D.G.; Zhou, G.; Zhang, N.; Jin, C. Interactions of fungi with concrete: Significant importance for bio-based self-healing concrete. Constr. Build. Mater. 2018, 164, 275-285. [CrossRef]

25. Menon, R.R.; Luo, J.; Chen, X.; Zhou, H.; Liu, Z.; Zhou, G.; Zhang, N.; Jin, C. Screening of fungi for potential application of self-healing concrete. Sci. Rep. 2019, 9, 2075. [CrossRef] [PubMed]

26. Durastanti, C.; Moretti, L. Environmental Impacts of Cement Production: A Statistical Analysis. Appl. Sci. 2020, 10, 8212. [CrossRef]

27. Babor, D.; Plian, D.; Judele, L. Environmental impact of concrete. Bul. Inst. Politeh. Din Lasi. Sect. Constr. Arhit. 2009, 55, 27.

28. Pahazri, N.F.; Mohamed, R.M.S.R.; Al-Gheethi, A.A.; Kassim, A.H.M. Production and harvesting of microalgae biomass from wastewater: A critical review. Environ. Technol. Rev. 2016, 5, 39-56. [CrossRef]

29. Zheng, M. Molasses Spill Endangers Marine Life. 2013. Available online: https://www.manoanow.org/kaleo/opinion/ environment/molasses-spill-endangers-marine-life/article_b28edbfa-44f0-11e3-92e8-0019bb30f31a.html (accessed on 20 September 2021).

30. Sahai, D. Cement Hazards and Controls: Health Risks and Precautions in Using Portland Cement. Available online: https:/ / elcosh. org/document/1563/d000513/cement-hazards-and-controls-health-risks-and-precautions-in-using-portland-cement.html (accessed on 24 September 2021).

31. Prasad, R. Fertilizer nitrogen, food security, health and the environment. World 2001, 16, 14-16.

32. Peighambarzadeh, F.S.; Asadollahfardi, G.; Akbardoost, J. The effects of using treated wastewater on the fracture toughness of the concrete. Aust. J. Civ. Eng. 2020, 18, 56-64. [CrossRef]

33. Asadollahfardi, G.; Mahdavi, A.R. The feasibility of using treated industrial wastewater to produce concrete. Struct. Concr. 2019, 20, 123-132. [CrossRef]

34. Fraile-Garcia, E.; Ferreiro-Cabello, J.; López-Ochoa, L.M.; López-González, L.M. Study of the technical feasibility of increasing the amount of recycled concrete waste used in ready-mix concrete production. Materials 2017, 10, 817. [CrossRef]

35. Mazzei, L.; Musiani, F.; Ciurli, S. The structure-based reaction mechanism of urease, a nickel dependent enzyme: Tale of a long debate. JBIC J. Biol. Inorg. Chem. 2020, 25, 829-845. [CrossRef] [PubMed]

36. Moreno-Garcia, L.; Adjallé, K.; Barnabé, S.; Raghavan, G.S.V. Microalgae biomass production for a biorefinery system: Recent advances and the way towards sustainability. Renew. Sustain. Energy Rev. 2017, 76, 493-506. [CrossRef] 